\title{
Volume 2, Issue no. 2
}

\section{Introduction}

n December 2009, a group of working life researchers met in Copenhagen to discuss what could be done to restore relationships in this subject area in the Nordic countries. The starting point of our discussions was the recognition that our collaboration had weakened over the last 10-15 years. We decided, therefore, to establish a journal and resume a tradition of organizing a Nordic working life conference, preferably every second year.

You are now reading the fourth issue of the journal, and from 25th to 27th of April 2012 the seventh Nordic Working Life Conference was held in Elsinore in Denmark after a break of 13 years! It was a very successful conference with over 100 papers, the majority of which can be downloaded from http://www.sfi.dk/paper_upload-10624. aspx. The conference confirmed that the Nordic working life research has a special flavor - due to the characteristics of the working life in the Nordic countries and a research tradition that we believe is distinct, given the high relative density of this kind of research in our part of the world. Our strong belief, therefore, is that the conference is worth nurturing, maintaining, and developing.

It was concluded that the renewed interest for Nordic collaboration must not become an isolationist effort. Nordic working life research is not and can never be enough in itself. The Nordic countries are unique in certain aspects that impact the work-life relationship: a relatively high degree of equality, high levels of participation, a welldeveloped welfare state, and a comparatively high degree of organization of labor. However, this is increasingly challenged from internally and externally - from both local and global forces. We have a lot to learn from the international research community, and hopefully also vice versa. Nordic working life research is thus an integrated part of the broader international research in this field.

The conference in April 2012 confirmed both through the papers that were presented and the more informal exchange of ideas, views, and experience that it is valuable to maintain a Nordic perspective on working life - without reducing the need for a European and global perspective.

Klaus T. Nielsen had the challenging task at the last session of the conference to summarize the impressions and inspirations from the conference. Some of these he presents in this issue.

The articles in this issue reflect in different ways Nordic conditions and perspectives:

- Equality, which is relatively high in the Nordic countries, is not a restriction on the creation of jobs and employment. In fact, it can contribute (see Barth and Moene's article).

- The strong Nordic unions are challenged by changes in work organization (see Lind and Voxted). 
- In the Nordic countries, there is a belief that participation and involvement create successful change. However, that is not always the case (see Bjørnstad and Kari Steen-Johnsen's article).

- Despite relatively tight regulation, the risk of accidents is much higher for young employees, also in the Nordic countries - why so? (see Lykke Nielsen's article).

I offer a synopsis of the subject focus and key highlights of the four articles:

Erling Barth and Karl Ove Moene give an important contribution to the understanding of the economic consequences of equality. Barth and Moene examine the effects of wage differentiation on employment. Is it true that high minimum wages reduce employment among low-skilled workers, because they do not have a productivity that equals their salary? And is it so that restrictions on higher wages will reduce dynamism and growth in the economy? These are arguments that flourish in the public debate on salary, equality, and employment. Barth and Moene analyze wage differences and employment rates in the OECD countries and suggest that common interpretations are wrong. Wage compression seems to be associated with high employment rates. This also applies to those who are most at risk: young and unskilled workers. The employment rate is higher for this group in countries with relatively high minimum wages. The positive employment effect of wage compression is particularly true in countries where wage policies lift the bottom and at the same time restrict wage growth at the top.

Barth and Moene find different theoretical explanations for this controversial finding. They draw on the theoretical justifications of the solidarity wage policy in the Nordic countries. They highlight that high minimum wages tend to eradicate low-productivity jobs and thus contribute to the allocation of investments to productive jobs. In addition, a limitation on high salaries is making highly productive production more cost-effective. Barth and Moene also argue that high and indispensable minimum wages discourage employers to speculate in reducing employment to reduce wages because the wage level is already fixed. Barth and Moene's article is thus a strong argument for solidarity wage policy and centralized wage bargaining to reduce wage differentials.

Jens Lind and Soren Voxted contribute to the understanding of the declining membership in the trade unions. In Denmark, Sweden, and Finland, the share of unionized employees was increasing until the mid-1990s, when around $80 \%$ of workers were organized in a union. Today, the level has declined to around $70 \%$. In Norway, the decrease started earlier. In Denmark and in the other Nordic countries, the decline of membership has especially taken place in the LO unions (members of the Confederation of Trade Unions, predominantly organizing manual workers), while membership is increasing in trade unions for professionals and semiprofessionals. There are many reasons for this decline: structural changes in the labor market, changes in labor market regulation, and individualization. Lind and Voxted, however, identify another reason for the decline in membership that has not yet been properly examined: an increasing number of employees received leadership assignments, and many of them feel therefore that they do not belong in the traditional trade unions. Lind and Voxted note that in Denmark, around 2500 members of the LO are shifting to the Danish Association of Managers and Executives every year. One reason for the decline of members in LO seems to be that the there are "too many Chiefs and not enough Indians." Many of those joining the Danish Association of Managers and Executives have no formal leadership position, but are team leaders, project coordinators, responsible for quality 
assurance, etc. Lind and Voxted argue that the changes taking place in work organizations soften the boundaries between managers, workers, and staff and that a much larger proportion of employees are performing managerial duties. If the unions want to adhere to these members, they must orient themselves to these members' needs and their social orientation in the workplace.

Thor Christian Bjørnstad and Kari Steen-Johnsen address a common phenomenon in the social life that is rarely discussed in the literature: failing projects. In the Norwegian part of a major American logistics and transportation company, a work site health promotional project was initiated. The project was provided by the Norwegian Federation of Company Sports (NFCS). NFCS based their activities on a long Norwegian tradition of cooperation, involvement, and democracy. The project was thus based on involvement of all parties in the company. Employees, including those at the shop floor, should be actively involved in the project's development. The assumption was that if the project was based on employees' active participation, the project would gain support and be an ongoing activity in the company. The prerequisites for such a participatory approach to the project turned out, however, not to be present in this case.

Centralized planning, strict managerial systems, and narrow focusing on individual performance dominated the company. The health promotion project was thus based on a completely different organizational logic than the organizational logic that dominated the company. This was according to the authors the main reason for the failure of the project. Although the project had the resources, and although managers at higher levels participated in the steering committee of the project, the project failed. A series of initiatives were launched, but they all lost momentum, and the project did not have any lasting effect.

Mette Lykke Nielsen writes about an ancient but still very topical issue: workrelated accidents among young people. The risk of being exposed to an accident is $50 \%$ higher for young people between 18 and 24 years than more experienced employees. Nielsen in her analysis uses a narrative approach to the occupational hazard for young people. She identifies a narrative among experienced employees and managers saying that young people are more willing to take a risk than older people: "they do not think twice" and "they think they can walk on water" were common expressions in the narrative. Through 23 in-depth interviews with young people on work-related risks they experienced, Nielsen presents a different understanding of risk behavior among young employees. Their risk behavior originates most of all from their attempts to "adapt to the normal." Nielsen shows how young people are introduced to what are perceived as acceptable risks in the workplace and how young people are positioned in tasks and duties that are particularly risky to newcomers and the inexperienced. The elevated risk for young people is related to the position the youth is assigned to and acts from.

Read, reflect, and enjoy!

Helge Hvid 